\title{
Practices and Ways of Doing Things in the World Trade Organization (WTO) Law
}

\author{
Gabrielle Marceau \& Clément Marquet"
}

\section{Introduction}

Contracting Parties to the 1947 General Agreement on Tariffs and Trade (GATT 1947) created the World Trade Organization (WTO). The GATT 1947 was not a formal international organization and in fact it never wanted to be an autonomous treaty. Instead, the GATT 1947 was a temporary agreement, entering into force on 1 January 1948 provisionally; its text and schedules were to be integrated into the Charter creating the International Trade Organization (ITO), constituted by the Havana Charter. However, the treaty which was to create the ITO never entered into force due to, in particular, the refusal by the US Administration to ratify it. ${ }^{1}$ The GATT 1947, more modest and deprived of the institutional provisions that the ITO would have brought, remained in force on a provisional basis until 1 January 1995 when the WTO came into force.

Soon after the implementation of the GATT, trade between Contracting Parties increased; ${ }^{2}$ the GATT had to be operational despite its institutional weaknesses and legal uncertainties. This may explain why pragmatism and flexibility are characteristic elements of the GATT legal order. ${ }^{3}$ The Contracting Parties were led to adopt several types of instruments, all without

* Gabrielle Marceau, PhD, is Counsellor in the Legal Affairs Division of the WTO Secretariat and Associate Professor at the University of Geneva.

1 In December 1950, it became clear that the United States would never ratify the ITO treaty. See J. H. Jackson, World Trade and the Law of GATT (1969), 50.

2 WTO Secretariat, World Trade Report 2007 (2007), 243.

3 See for that purpose Jackson, supra note 1; R. Hudec, The GATT Legal System and World Trade Diplomacy (1975). See in particular G. Berrisch, who wrote: "The GATT legal system is often seen as a flexible one with a very flexible approach to the treatment of conflicts between its Contracting Parties. [...] Flexibility and pragmatism are, therefore, characteristic elements of the GATT legal order", in G. M. Berrisch, The Establishment of New Law Through Subsequent Practice in GATT, 16 North Carolina Journal of International Law and Commercial Regulations (1991), 497, 498. 
any clear status: decisions specifying, adding to or even amending the wording of the Agreement, guidelines, statements ("rulings" and "statements") of the Chairman, adopted by consensus of Contracting Parties. ${ }^{4}$ These acts and decisions were respected and often seem to have been followed by a consistent and sometimes progressive practice. The Contracting Parties, individually or jointly, also developed several "ways of doing" which evolved throughout the years. In that context the GATT forum teemed with specific ways of doing things in the implementation of the GATT mechanisms, in the functioning of the Council meetings, Committees, etc., and in its dispute settlement system. In fact, the GATT's achievement lies in that, with these multiple (soft) practices, it succeeded in prolonging, strengthening and expanding an incomplete provisional agreement for almost 50 years until the WTO. Those practices can have varying degrees of intensity, stem from different types of authors, and be perceived as more or less binding by WTO Members. Moreover, the transition from the GATT to the WTO adds a layer of complexity, because some of the GATT practices were codified into the new treaty whilst others were mentioned as "guidelines" in the interpretation of the WTO.

There are all sorts of practices in international law generally and questions therefore necessarily arise regarding what legal status those practices have reached. In this chapter, we first present "practices" in international law, before reviewing all sorts of practices and ways of doing things, under the GATT and now in the WTO and discussing their operation.

\section{The practice in international law: At the crossroad of various concepts}

\section{A. The practice in general international law}

The notion of practice can first be defined as a formal practice either as: 1) an autonomous source of obligation and the basis for a legal claim, as mentioned in Article 38(1)(b) of the Statute of the International Court of Justice - as components of customary international law; or 2) as a source of interpretation within the meaning of Article 31(3)(b) of the Vienna Convention on the Law of Treaties (VCLT), as part of the "subsequent practices of the (treaty) parties", composing the (broad) context that should be taken

4 General Agreement on Tariffs and Trade 1947, 30 October 1947, 55 U.N.T.S. 194, (GATT 1947). Article XXV provides that when the "collectivity" of Contracting Parties acts, it shall be described as the CONTRACTING PARTIES. 
into account when interpreting a term of a treaty. However, authors seem to consider the latter a subcategory of the former. ${ }^{5}$ Subsequent practice in the VCLT, given its role and effect in the interpretation and possibly the amendment ${ }^{6}$ of treaties, should be seen as a subdivision of customary international law. In doing so, those authors promote a unified notion of practice.

The title of this subsection is voluntarily ambiguous, as it underlines a debate that has not yet been settled. Indeed, authors have varying opinions regarding the actual reach and scope of subsequent practice. Some argue the concept that the only possible use of practice is to give a clearer definition of what the treaty already encompasses. ${ }^{7}$ Others, however, consider that subsequent practice can become the source of obligations that can reach further than in the first approach, be it because the parties creating the subsequent practice are considered "masters of their treaty", ${ }^{8}$ or because the division between those two concepts cannot be clearly established. ${ }^{9}$ If both concepts of practice are interlinked and sometimes mixed in general international law, the distinction between them is crucial in WTO law because the WTO substantive obligations are only those included in the covered agreements (seemingly excluding the possibility of WTO customary law).

5 R. Kolb, La bonne foi en droit international public (2000), 507-508.

6 The amendment of treaties through subsequent practice is a controversial subject. On that topic, see I. Sinclair, The Vienna Convention on the Law of Treaties, $2^{\text {nd }}$ ed. (1984), 138; H. Fox, Article 31(3)(A) and (B) of the Vienna Convention and the Kasikili/Sedudu Island Case, in M. Fitzmaurice et al. (eds.), Treaty Interpretation and the Vienna Convention on the Law of Treaties: 30 Years on (2010), 59, 61; M. G. Kohen, Keeping Subsequent Agreements and Practice in Their Right Limits, in G. Nolte (ed.), Treaties and Subsequent Practice (2013), 34, 35-36; Second report on subsequent agreements and subsequent practice in relation to treaty interpretation by Georg Nolte, Special Rapporteur, UN Doc A/CN.4/671, 26 March 2014, paras. 115-142; Kolb, supra note 5, 479-480.

7 See for instance Methanex Corporation v. United States of America, Second Opinion of Professor Sir Robert Jennings, Q.C., 6 September 2001 available at http://www.italaw.com/sites/default/files/case-documents/ita0983.pdf (last visited 6 December 2018).

8 O. Dörr, K. Schmalenbach, Vienna Convention on the Law of Treaties - A Commentary (2012), 555, para. 76.

9 As Sinclair put it: "It will be apparent that the subsequent practice of the parties may operate as a tacit or implicit modification of the terms of the treaty. It is inevitably difficult, if not impossible, to fix the dividing line between interpretation properly so called and modification effected under the pretext of interpretation." Sinclair, supra note 6,138 . 
Coming back to the topic at hand, as a corollary from the link between custom and subsequent practice, it should be noted that both entail not only an objective, but also a subjective element. Article 38(1)(b) specifically requires custom to be constituted of both state practice and opinio juris. Subsequent practice in Article 31(3)(b), for its own part, refers to the subjective element through the wording "which establishes the agreement of the parties regarding its interpretation".

As Boisson de Chazournes puts it:

[...] subsequent practice is, at its core, fairly uniform. To consider it as a blend of repetition over time with acknowledgement appears to be a firmly rooted assumption for international lawyers. ${ }^{10}$

However, as is the case in the context of custom, the importance of the subjective aspect is debated across a wide spectrum. At one end of that spectrum, some authors defend a concept of custom in which practice is the alpha and the omega. In this approach, the objective element of custom serves as an indicator of the subjective opinion of the State promoting it, thus creating a kind of presumption of opinio juris. ${ }^{11}$ Judge Lachs discussed the question of custom in his dissenting opinion:

What can be required is that the party relying on an alleged general rule must prove that the rule invoked is part of a general practice accepted as law by the States in question. No further or more rigid form of evidence could or should be required. ${ }^{12}$

Somewhere in the middle, others consider that the subjective and the objective should go hand in hand, perceiving them as "two sides of the same coin which, like heads and tails, may differ but which cannot exist separately." ${ }^{13}$ At the other end of the spectrum, some authors insist on the pri-

10 L. Boisson de Chazournes, Subsequent Practice, Practices, and "Family-Resemblance”: Towards Embedding Subsequent Practice in its Operative Milieu - A Multi-Actor Perspective, in G. Nolte (ed.), Treaties and Subsequent Practice (2013), 53, 54.

11 See H. Kelsen, Principles of Public International Law, $2^{\text {nd }}$ edition (1966), 450-451.

12 North Sea Continental Shelf (Federal Republic of Germany v. Netherlands), Judgment, ICJ Reports 1969, 3, Judge Lachs Dissenting Opinion, 218, 231.

13 R. Müllerson, The Interplay of Objective and Subjective Elements in Customary Law, in K. Wellens (ed.), International Law: Theory and Practice: Essays in Honour of Eric Suy (1998), 161, 166. 
mordial importance of this subjective element, going as far as denying the role of practice. ${ }^{14}$

It must nevertheless be noted that, if kicked through the door, the subjective element comes back through the window. Indeed, another criterion of subsequent practice mentions that the inaction or silence of states can be construed as acceptance. The ICJ's case law also tends to confirm this approach. As it explained in the context of Article 31(3)(a), subsequent agreements can be born through the inaction of a State in a situation where it should have reacted. ${ }^{15}$ If a subsequent agreement can be born out of mere acquiescence, it could be conceived that the less formalistic subsequent practice can arise from a State's inaction or silence. ${ }^{16}$ The ICJ indirectly confirms this vision in the Kasikili/Sedudu case:

To establish such practice, at least two criteria would have to be satisfied: first, that the occupation of the Island by the Masubia was linked to a belief on the part of the Caprivi authorities that the boundary laid down by the 1890 Treaty followed the southern channel of the Chobe; and, second, that the Bechuanaland authorities were fully aware of and accepted this as a confirmation of the Treaty boundary. ${ }^{17}$

This confirmation of the possibility to create subsequent practice out of inaction or silence indicates that a State opposing the development of a prac-

14 B. Cheng, United Nations Resolutions on Outer Space: 'Instant' International Customary Law?, in B. Cheng (ed.), Studies in International Space Law (1997), $125,138$.

15 "In fact, as will be seen presently, an acknowledgment by conduct was undoubtedly made in a very definite way; but even if it were otherwise, it is clear that the circumstances were such as called for some reaction, within a reasonable period, on the part of the Siamese authorities, if they wished to disagree with the map or had any serious question to raise in regard to it. They did not do so, either then or for many years, and thereby must be held to have acquiesced. Qui tacet consentire videtur si loqui debuisset ac potuisset." Case concerning the Temple of Preah Vihear (Cambodia v. Thailand), Merits, Judgment, ICJ Reports 1962, 6, 23.

16 This reasoning only applies to "subsequent practice" in the context of Article $31(3)(\mathrm{b})$, and its relation to "subsequent agreements" in the meaning of Article 31(3)(b). "Practice" as a component of customary international law should not be understood as having a lower binding force than international agreements. It is indeed usually considered that there is no hierarchy between Article 38(1)(a) and $38(1)$ (b) of the ICJ Statute; see A. Pellet, Article 38, in A. Zimmermann et al. (eds.), The Statute of the International Court of Justice: A Commentary, $2^{\text {nd }}$ ed. (2012), 731, 841.

17 Kasikili/Sedudu Island (Botswana v. Namibia), Judgement, ICJ Reports 1999, 1045, 1094, para. 74 (emphasis added). 
tice should show its intention in this regard. ${ }^{18}$ The State's opinion on the matter therefore remains relevant.

A final point deserves to be made regarding the difference between subsequent practice and subsequent agreement (within the meaning of Article 31(3)(a) VCLT) since both of them seem to include both an objective and subjective element. Nolte, in his work on the subject, explained the difference as follows:

Subsequent agreements and subsequent practice are distinguished according to whether a common position can be identified as such, in a common expression, or whether it is necessary to indirectly identify an agreement through particular conduct or circumstances. ${ }^{19}$

The overall difference, according to him, stems from the visibility of the agreement, formal or informal. ${ }^{20}$ In the absence of such visibility, the interpreter should resort to practice, as the expression of a possibly underlying agreement. This approach is also defended by Fox, who underlines that the notion of subsequent agreement "appears to insist on an element of common intent of the parties and hence distinguishes it from mere practice of the parties".21

\section{B. The authors of the practice}

Various questions stem from the issue of practice ratione personae. The first one regards who can be seen as the authors of such subsequent practice, and whether they need to be active authors. This was already briefly discussed above, but it is quite uncontested that practice does not have to be

18 This could be likened to the concept of the persistent objector found in customary international law. On this topic, see J. L. Charney, The Persistent Objector Rule and the Development of Customary International Law, 56 British Yearbook of International Law (1985), 1.

19 First report on subsequent agreements and subsequent practice in relation to treaty interpretation by Georg Nolte, Special Rapporteur, UN Doc A/CN.4/660, 19 March 2013, para. 74.

20 The ICJ also seems to consider the formality (or lack thereof) of the agreement to be somewhat irrelevant, see Kasikili/Sedudu Island (Botswana v. Namibia), Judgement, ICJ Reports 1999, 1045, 1087, para. 63.

21 Fox, supra note 6, 64. 
actively accepted by all the parties involved. ${ }^{22}$ Mere silence from a State can already be construed as acceptance of a practice, rendering it binding. As Judge Weeramantry put it in his dissenting opinion in the Kasikili/Sedudu case:

I accept Namibia's submission that the word 'agreement' in Article 31, paragraph 3 (b), of the Vienna Convention can be read in the sense of 'understanding, and can therefore cover silence and inaction as well. This view derives support not only from the general law relating to the interpretation of documents, but also from the travaux préparatoires of the Convention. In paragraph 49 of its Judgment, the Court likewise gives its support to the view that the Parties' understanding of the Treaty is the basis for the importance of subsequent practice. ${ }^{23}$

A second question regarding the authors of the subsequent practice deserves our attention; who are the entities whose practice is relevant to consider in the context of Article 31(3)(b) of the VCLT? ${ }^{24}$ As a preliminary point, as envisioned by Article 5 of the VCLT, the convention "applies to any treaty which is the constituent instrument of an international organization". In this specific situation, Article 31 and 32 would be applicable, and therefore influence the outcome of the interpretative process. ${ }^{25}$ The VCLT would be applicable as a whole to the treaty under scrutiny and the practice arising from it could potentially qualify as "subsequent practice" in the sense of Article 31(3)(b). Secondly, the wording of the convention can be taken into account: the VCLT does not refer to "state practice", but rather to "the parties". Secondly, as Nolte underlines in the first Report of the Special Rapporteur of the ILC on subsequent practice, "article 31(3)(a) of the Vienna Convention speaks of any subsequent agreement 'between

22 Dörr, Schmalenbach, supra note 8, 557 para. 83; Second report on subsequent agreements and subsequent practice in relation to treaty interpretation by Georg Nolte, Special Rapporteur, UN Doc A/CN.4/671, 26 March 2014, para. 60.

23 Kasikili/Sedudu Island (Botswana v. Namibia), Judgement, ICJ Reports 1999, 1045, Dissenting opinion of Judge Weeramantry, 1153, 1159-1160.

24 For a general overview of Article 31 of the VCLT, see G. Marceau, WTO Dispute Settlement and Human Rights, 13 European Journal of International Law (2002), 753, 779-786.

25 Report of the International Law Commission on the work of its sixty-eighth session, 2 May-10 June and 4 July-12 August 2016, UN Doc A/71/10, 223-227. 
the parties', article 31(3)(b) merely speaks of 'subsequent practice in the application of the treaty."26

Following this approach, we could deduce from the difference in wording that the practice under consideration does not need to stem from the parties directly, but should rather be an indication of their agreement on the matter. This leads to the question ratione personae, whereby one can wonder whether practice by organs of an international organization qualifies as "subsequent practice" within the meaning of Article 31(3)(b) of the VCLT. The decisive criterion regarding the possibility to attribute an international organization's conduct to state practice is usually how reflective the former is of the latter. ${ }^{27}$ This approach, however, does not specifically establish the ability of a body to create subsequent practice by itself. It would only be relevant insofar as said practice mimics the states' practice and opinio juris.

Another approach can be taken, however, in which practice by the organs of an international organization is not attributed to the states, but directly to the international organization itself. As evidenced by Nolte, the ICJ has referred on multiple occasions to the use of subsequent practice of an organization's organs in interpretative reasoning. ${ }^{28}$ The extent to which the subsequent practice of the international organization's organs can be taken into account partially depends on the focus of the interpretation, and the weight of those practices in the interpretation process is nevertheless debated. It is indeed unclear whether this practice would only qualify as a mere supplementary means of interpretation (within the meaning of

26 First report on subsequent agreements and subsequent practice in relation to treaty interpretation by Georg Nolte, Special Rapporteur, UN Doc A/CN.4/660, 19 March 2013, para. 119.

27 The ICJ itself seems to indicate this in the Whaling case, by underlining the fact that the International Whaling Commission's resolutions could not be accepted as subsequent practice precisely because it did not reflect the agreement of all the parties, and in particular not that of Japan, see Whaling in the Antarctic (Australia v. Japan: New Zealand intervening), Judgment, ICJ Reports 2014, 226, 257, para. 83; See also G. Nolte, Subsequent Agreements and Subsequent Practice, Report 3, G. Nolte (ed.), Treaties and Subsequent Practice, 307, 381.

28 Third report on subsequent agreements and subsequent practice in relation to treaty interpretation by Georg Nolte, Special Rapporteur, UN Doc A/CN.4/683, 7 April 2015, para. 43-56 and references. 
Article 32 of the VLCT $)^{29}$ or as a more primary interpretative tool..$^{30}$ Moreover, should the object of the interpretation not be the "constituent instrument" of an international organization, authors seem to recognize that its practice would still qualify as a means of interpretation falling under Article 32 of the VCLT. ${ }^{31}$

With regard to the organ's working methods and composition, Lauterpacht underlines that:

Generally, no special emphasis has been laid on the character of the vote - whether unanimous or majority - which has occasioned the conduct in question. ${ }^{32}$

One can still wonder whether the type of vote could influence the strength and the binding character of the subsequent practice. In other words, could a unanimous or consensual vote mean a higher degree of reliability of the practice in further interpretation of a given treaty? Similarly, one could wonder whether, and to what extent, the composition of the organ under scrutiny could influence the weight given to its practice during the interpretation process. Should the practice of an integrated organ hold the same weight as a political organ, or a plenary organ compared to a restricted membership body?

\section{The practice as soft law?}

Finally, another approach to practice should be underlined. The very notion can be understood in different ways. Indeed, while the practice can be brought up in the context of Article 31, it is certainly not limited to it. The practice can also be understood in a softer approach in which it only reflects a habit whose legal status is much less clear. These ways of doing (to avoid the expression "practice") could nevertheless influence the behaviour

29 S. Kadelbach, Interpretation, in Simma et al. (eds.), The Charter of the United Nations: A Commentary, $3^{\text {rd }}$ ed. (2012), 71, 85-86.

30 For instance, the ICJ had recourse to the practice of an international organization with regard to Article 31(1), when discussing the purpose and function of a treaty: Reparations for injuries suffered in the service of the United Nations, Advisory Opinion, ICJ Reports 1949, 174, 180.

31 Report of the International Law Commission on the work of its sixty-eighth session, 2 May-10 June and 4 July-12 August 2016, UN Doc A/71/10, p. 225.

32 E. Lauterpacht, The Development of the Law of International Organizations by the Decisions of International Tribunals, 152 Collected Courses of the Hague Academy of International Law (1976), 377, 458. 
of states. Boisson de Chazournes underlines the nuance between the different acceptations of the word "practice" in these words:

Such a conceptual homogeneity, however, is blurred by the fact that some conventional regimes have practices that do not match the logic of custom. The hiatus can have to do with process of practice production, e.g. "environmental best practices", or the actors involved, e.g. "commercial uses", or even both, e.g. "technical standards". Common to all these practices is the lack of consistency and endorsement necessary in tandem for custom development and, in turn, usually ascribed to subsequent practice. Nonetheless, these practices impact upon states' behaviour under the treaty and, what is more, they play a role in the judicial or quasi-judicial application of treaties. It suffices to note, for the time being, that a number of international judicial instances ranging from the World Trade Organization (henceforth, WTO) Panels and Appellate Body to the International Tribunal for the Law of the Sea (ITLOS) or to arbitral tribunals - have referred to technical standards, best practices and so forth. ${ }^{33}$

This notion of ways of doing would therefore cover a kind of practice whose status cannot quite be defined in the same terms as those falling under Article 38(1)(b) of the ICJ Statute or 31(3)(b) of the VCLT.

We can draw from the above that some "practices" serve mainly a functional purpose allowing for predictability in a given system. States, however, do not usually feel formally bound by those ways of doing. These could be compared to a sort of gentlemen's agreement, for which "the rights and obligations created [are] deemed to be moral, not legal." ${ }^{4}$ It is therefore left out of the normative realm upon the inception of the rule, but does not preclude it from becoming, later on, binding international law through the usual mechanisms of practice mentioned above.

\section{The GATT's practices: what pragmatism requires}

\section{A. The GATT as a de facto UN specialised agency}

The GATT itself, by force of circumstance and practice, evolved into a de facto international organization. When it became obvious that the creation

33 Boisson de Chazournes, supra note 10, 54.

34 J. Klabbers, The Concept of Treaty in International Law (1996), 16. 
of the ITO would be indefinitely postponed, the Contracting Parties gave the GATT Executive Secretary the responsibility to consult the UN about practical arrangements to be agreed upon. ${ }^{35}$ On 11 August 1952, the GATT Executive Secretary and the UN Secretary-General exchanged letters confirming that, having regard to de facto arrangements existing between ICI$\mathrm{TO}^{36}$ Secretariat and the UN, it was not necessary to conclude a special or formal agreement with respect to the GATT. ${ }^{37}$ These arrangements included the participation in the Common System of Salaries and Pensions, the participation of the GATT's Secretary-General in the Administrative Committee on Coordination (ACC) and its subsidiary bodies, and the opportunity to benefit from all of the rights granted to specialised agencies pursuant to the main agreements governing their relationships with the UN, namely the exchange of information and documents, reciprocal representation at meetings and coordination activities, as well as the participation in inter-institutional bodies.

The GATT never concluded any agreement with the UN as a specialised agency, nor was any other formal arrangements created. But, throughout its whole existence, the GATT was perceived as an international organization and behaved as such. In addition to de facto arrangements with the UN, the GATT entered into other international commitments, such as the creation, with UNCTAD, of the International Trade Centre (ITC) in $1967 .{ }^{38}$ The GATT Secretariat was the forum of eight negotiation rounds and its frameworks saw the birth of other agreements, such as the Tokyo Round and the Uruguay Round. These de facto arrangements were forms of practices which continued until the WTO.

\section{B. The development of various institutional practices}

\section{In the functioning of the GATT Council and Committees and the Tokyo Round Committees}

Throughout the existence of the GATT, institutional practices developed and covered a range of subjects. As of 1960, Contracting Parties created the

35 See Document GATT/CP.6/41, 24 October 1951.

36 Interim Commission of the International Trade Organization.

37 See Document GATT G/16, 11 August 1952.

38 See Document GATT L/2839, 31 August 1967. 
"Council of Representatives" 39 by a simple decision of the Council. Following this date, all of the Contracting Parties' actions were carried out through the intermediary of the Council, made up of representatives of Contracting Parties.

To mention only a few other noteworthy practices: postal (and sometimes telegraph) ballot was constantly used for decisions concerning waivers or accessions; the 10-calendar days rule that remained unwritten for a long time (until the nineties) ${ }^{40}$ was used for registering items in the agenda of the Council of Representatives; and the quorum was never officially recorded during the meetings. This last issue raises questions regarding the possibility of developing subsequent practice in the context of Committees or Councils. As mentioned above, their decision should ultimately be attributable to States. Still, possible lack of actual reflection of the Members' intention, or even lack of proof, could jeopardize this ability to attribute.

Following the increasing institutionalization of the GATT through the Uruguay Rounds and what was supposed to arise from it, from 1985 to 1993 the Secretariat and the Contracting Parties sought to strengthen some practices or facilitate their application. For this reason, invitations to the GATT's annual or ministerial sessions, or to negotiations, which had been so far ad personam, were issued in the form of an impersonal Aerogramme. The change in nature of the Council's report at the annual session also dates back to this time, as well as the agreement pursuant to which any discussion under "Other issues" in the Council's agenda of meetings could only be provisional and have no expectation that a decision would be taken. ${ }^{41}$ Furthermore, should a Member desire to contest an item on the agen$\mathrm{da}$, it was this particular point that was challenged and not the whole agenda. All of these re-defined practices, as well as the computerization of the Secretariat, greatly contributed to improving the effectiveness of the GATT's operations, while laying the foundations for a smooth transition towards the WTO. ${ }^{42}$

39 See Document BISD 9S/8, 4 June 1960.

40 This is reflected today in Rules 2 and 4 of the General Council's Rules of Procedure.

41 This is reflected today in Rule 25 of the General Council's Rules of Procedure.

42 We hereby thank Claude Mercier, Former Director at the WTO's Institute for Training, who joined the GATT in 1973, for sharing with us his knowledge on that subject. 


\section{In the administration of the system of dispute settlement}

a. The creation of panels and the general evolution of the system of dispute settlement

Article XXIII of the GATT 1947 mentions that the Contracting Parties shall be referred any question relating to the application of the GATT's provisions. During GATT's first decade, the Contracting Parties employed "decisions by the Council Chairman" (rulings). Then, they turned to the creation of a panel of experts. ${ }^{43}$ The first report issued by a panel of five experts appointed by agreement of the parties, related to the case "Uruguayan Recourse to Article XXIII" in 1962.44 Throughout the years and experiences, the Contracting Parties adopted various forms of decisions which detailed and strengthened the system of dispute settlement.

The development of practices touched upon a broad range of matters, such as the exchange of written submissions, the holding of hearings, the questions raised by Members of the panel and the presentation of a report to the Contracting Parties. Pescatore, Davey and Lowenfeld praised the development of the GATT system of dispute settlement which was based on the modest provisions of Articles XXII and XXIII of the GATT 1947:

The development of these minimal bases into a relatively successful system of dispute settlement is one of the most remarkable examples of pragmatic achievements in the sphere of international law. The purely experimental operation of the provisions of Articles XXII and XXIII lasted for a long time - in fact until the completion of the Tokyo Round in 1979 [...]. ${ }^{45}$

During the Tokyo Rounds, the Contracting Parties codified various practices from the system of dispute settlement in an "Understanding Regarding Notification, Consultation, Dispute Settlement and Surveillance" 46 completed by an annex entitled "Agreed Description of the Customary Practice of the GATT in the Field of Dispute Settlement". These two texts specified the first parameters of practices, procedures and princi-

43 The possibility for a panel to entertain a complaint was recognized in 1966, in the Decision to implement Article XXIII for the benefit of the least-developed countries (see Document BISD 14S/18, 5 April 1966, para. 5).

44 See Document BISD 11S/98, 16 November 1962 (GATT L/1923).

45 P. Pescatore et al., Handbook of GATT/WTO Dispute Settlement (1991), 7.

46 See Document GATT L/4907, 28 November 1979 (BISD, S26/231). 
ples in the GATT system of dispute settlement in accordance with their evolution at that time.

In 1982, the Ministerial Declaration which contained a Decision on "Dispute Settlement Procedure", further added details and refinements to the system without introducing any major amendment. ${ }^{47}$ In 1984, the Contracting Parties adopted a decision, in which the paragraphs of presentation recall the content of the Declaration of 1982. They further added that a clear commitment to the rules of procedure was necessary in order to improve the dispute settlement system. On this occasion, the Contracting Parties agreed on a test run of one year, during which those practices regarding panel procedures, time limit and follow-up of decisions would be adopted. ${ }^{48}$ This approach was indeed followed by the Contracting Parties (individually and jointly) and its development continued.

In July 1985, the Legal Affairs Office at the GATT Secretariat outlined, in a note intended for the newly established panels, the general procedures adopted by the Contracting Parties for the panels established under Article XXIII, paragraph 2, of the General Agreement, and suggested that the panels adopt the model working procedures indicated in the said note. ${ }^{49}$ As of this date, and until the entry into force of the WTO Understanding, the GATT's panels established under Article XXIII, Paragraph 2, regularly adopted these model procedures in their deliberations.

By decision adopted on 12 April 1989, the Contracting Parties applied the Ministerial Declaration of 1989 which included improvements to the rules and procedures governing the GATT's settlement of disputes; ${ }^{50}$ it was agreed that:

[...] panels shall follow the working procedures proposed in the Legal Affairs Office's note of July 1985, unless otherwise agreed by their members and in consultation with parties to the dispute. ${ }^{51}$

The WTO Understanding on rules and procedures governing the settlement of disputes (DSU) largely takes up the content of the Decision of 1989. ${ }^{52}$ The development of the practice followed by panels under the GATT was striking and responded to the changing needs of a more juris-

47 See Document BISD S29/14, 29 November 1982.

48 Provisions adopted on 30 November 1984 (BISD S31/9).

49 See Document GATT MTN.GNG/NG13/W/4, 10 June 1987.

50 See Document GATT L/6489, 12 April 1989.

51 Ibid., 6.

52 For a compilation of all instruments related to the system of dispute settlement under GATT see, Document MTN.GNG/NG13/W/4 Rev. 1, 10 November 1987. 
dictional and independent dispute settlement mechanism. Up until the final days of the GATT 1947, the Contracting Parties, by their actions, contributed to the development of practices of the system of dispute settlement that took root.

\section{b. The use of the so-called chairman statement}

The 10-day time-limit, during which a Member might give notification of its interest as third party, is another and more specific example of a procedural practice developed to respond pragmatically to the needs of the dispute settlement system. Since nationals from third parties may not, in principle, act as panel members, it became necessary to identify rapidly the Contracting Parties which had an interest in participating as a third party in order not to unduly delay the selection of panel members following their establishment by the DSB. Under the GATT, a Statement of the Council Chairman enshrined the practice of interested Contracting Parties being allowed to register their third party interests within a period of 10 days following the establishment of the panel. ${ }^{53}$ At the meeting held on 21 June 1993, the GATT General Council "accepted" this practice and thereby also codified it.

The minutes of this Council meeting recorded that the Chairman proposed that:

[T]he Council agrees to the hereinafter described practices, without prejudice to the rights of Contracting Parties under established dispute settlement procedures: a) delegations in a position to do so, should indicate their intention to participate as a third party in a panel proceeding at the Council session which establishes the panel. Others who wish to indicate a third party interest should do so within the next ten days; $[. .$.$] The Council agreed the Council agreed to the above-men-$ tioned practices. ${ }^{54}$

This practice was thereafter generally respected by the Contracting Parties, and today by WTO Members even in the absence of any provision provid-

53 See Document GATT C/COM/3, 21 June 1994.

54 Ibid. On this occasion, the representative of the United States also noted that the practice presented by the Chairman would be followed within the framework of the Understanding pursuant to which access to the submissions presented at a panel by parties to a dispute was almost identical to that provided for in one of the provisions of this Understanding. 
ing for a time-limit within which a third party must register its interest. However, in multiple cases, ${ }^{55}$ the parties accepted the participation of two developing countries as third parties, though their requests had been filed more than 10 days after the establishment of a panel.

Nowadays, the practice of chairmen's statements is more frequently used in the WTO. For instance, upon the accession of the Russian Federation, a last-minute issue arose regarding the French and Spanish translations of the Report of the Working Party on the Accession of the Russian Federation and the Schedules. In order to avoid delaying formal admission to the WTO, recourse was had to a chairman's statement (both by the Chairman of the Accession Working Party and by the Chairman of the Ministerial Conference), which declared that only the Protocol of accession would be considered authentic in the three official WTO languages, while the other document would only be authentic in English. ${ }^{56}$ This tool was also used in the context of the TRIPS amendment, whereby the chairman summed up the seemingly common understanding of the Members on various points regarding access to medicine. ${ }^{57}$

\section{The practice within GATT generated the WTO}

The GATT Contracting Parties created the WTO, and as the GATT cannot be defined without reference to the multiple practices which developed within, the creation of the WTO gave the opportunity to codify these practices.

55 Among others, United States - Subsidies on Upland Cotton (WT/DS267), EC Export Subsidies on Sugar (WT/DS266, 265, 283), Turkey - Measures Affecting the Importation of Rice (WT/DS334), United States - Measures Relating to Shrimp from Thailand (WT/DS343), EC - Tariff Treatment of Certain Information Technology Products (WT/DS375, 376, 377), China - Certain Measures Affecting Electronic Payment Services (WT/DS413), EC - Measures Prohibiting the Importation and Marketing of Seal Products (WT/DS400, 401), China - Measures Imposing Anti-Dumping Duties on High-Performance Stainless Steel Seamless Tubes ("HP-SSST") from the European Union (WT/DS460).

56 See Document WT/MIN(11)/SR/3, 20 April 2012, para. 6, 8, 9.

57 See Document JOB $(05) / 319,5$ December 2005. 


\section{A. General codification of GATT practices}

With the WTO, some of those GATT practices were continued, others were codified and even expanded - reinforcing the idea that the broad membership of the GATT was of the view such practice (sometimes contrary to the treaty or outside the treaty boundaries) had indeed adequately responded to their needs.

Article XVI:1 of the Marrakesh Agreement Establishing the World Trade Organization (the WTO Agreement) codifies in a general manner all of GATT's practices, procedures and decisions which must serve as a "guide" for the WTO:

Except as otherwise provided under this Agreement or the Multilateral Trade Agreements, the WTO shall be guided by the decisions, procedures and customary practices followed by the CONTRACTING PARTIES to GATT 1947 and the bodies established in the framework of GATT 1947. (emphasis added)

The GATT 1947 practices have never been formally listed. WTO Members, Councils, and Committees make reference to them when needed. While the continuation of these practices can be noted within various WTO bodies and in the behaviour of Members, often it is only when these practices come into contact with the dispute settlement system that their compulsory and binding nature, as well as their impact on the rights and obligations of WTO Members, can be assessed. Yet, in the WTO, practices, procedures and decisions of the GATT/WTO Members, Committees and Councils define the WTO itself and should therefore be assessed in relation to their purpose and their capacity to maintain a sound multilateral trade system which implies the respect of accountability principles.

\section{B. Codification of the practice of decision-making by consensus}

Article IX of the WTO Agreement codifies a fundamental GATT practice decision-making by consensus. However, it maintains the legal possibility to have a vote. 
The WTO shall continue the practice of decision-making by consensus followed under GATT 1947. ${ }^{58}$ Except as otherwise provided, where a decision cannot be arrived at by consensus, the matter at issue shall be decided by voting. At meetings of the Ministerial Conference and the General Council, each Member of the WTO shall have one vote. Where the European Communities exercise their right to vote, they shall have a number of votes equal to the number of their member States ${ }^{59}$ which are Members of the WTO. Decisions of the Ministerial Conference and the General Council shall be taken by a majority of the votes cast, unless otherwise provided in this Agreement or in the relevant Multilateral Trade Agreement. ${ }^{60}$

The practice of decision-making by consensus expanded with the WTO and we will discuss below the decision-making process within the WTO General Council and its other bodies. We will also tackle the issue of whether a uniform and sustained practice of Members who conform to decisions adopted by consensus, contrary to or in the absence of provisions of the treaty for that purpose, might provide for the implementation of these decisions within the framework of a WTO dispute settlement procedure; and whether the other Members might, in accordance with the general principle of estoppel, be barred in some circumstances, from exercising the right to challenge the validity of the decisions at issue.

\section{Codification of principles (and practices) developed under the GATT system of dispute settlement}

The principles (and practices) developed by the Contracting Parties in the system of dispute settlement have also been generally codified. Article 3.1 of the Dispute Settlement Understanding provides that:

58 [Original] The body concerned shall be deemed to have decided by consensus on a matter submitted for its consideration, if no Member, present at the meeting when the decision is taken, formally objects to the proposed decision.

59 [Original] The number of votes of the European Communities and their member States shall in no case exceed the number of the member States of the European Communities.

60 [Original] Decisions by the General Council when convened as the Dispute Settlement Body shall be taken only in accordance with the provisions of Paragraph 4 of Article 2 of the Dispute Settlement Understanding. 
Members affirm their adherence to the principles for the management of disputes heretofore applied under Articles XXII and XXIII of GATT 1947, and the rules and procedures as further elaborated and modified herein.

The use of the expression "principles" instead of "practices, procedures and decisions" may be explained by a willingness to reconcile the new specific procedures of the Understanding with the outcome arising from the evolution of 50 years of effective dispute settlement, reflected in the "principles" of this system.

\section{1. "GATT 1994"}

Another original form of codification of GATT practices is found in the creation of the concepts of the "GATT 1994"61 and the "GATT Acquis". But what is the "GATT Acquis" and what is it made of? And what is the difference with "GATT 1994"?

One of the components of Annex 1A, ${ }^{62}$ containing Multilateral Agreements on Trade in "Goods", is "GATT 1994" which together with twelve new agreements developed and expanded the disciplines of the GATT 1947. The GATT 1994 is made up of the text of the GATT 1947, six small interpretative agreements (called Memorandum), some of the GATT 1947

61 General Agreement on Tariffs and Trade 1994, 15 April 1994, 1867 U.N.T.S. 187, Marrakesh Agreement Establishing the World Trade Organization, Annex 1A, 1867 U.N.T.S. 154, (GATT 1994).

62 Annex 1A also contains 12 multilateral agreements on trade in goods. The WTO Agreement is composed of an institutional agreement and three annexes which form an integral part of it and constitute a "single agreement": Annex 1A contains multilateral agreements on goods, Annex 1B multilateral agreements on trade in services and Annex 1C the Agreement on intellectual property; Annex 2 includes the Dispute Settlement Understanding and Annex 3 the Agreement on the TradePolicy Review Mechanism. There is also an Annex 4 which contains today 2 plurilateral agreements binding only Members which adhered to it. 
Articles, ${ }^{63}$ protocols on accession and waivers, and decisions adopted by the Contracting Parties when the GATT existed. ${ }^{64}$

Discussing this question in one of its first reports in Japan - Alcoholic Beverages II, the Appellate Body recognized the existence of "practices" in WTO Law. It defined practices in accordance with the provisions of Article 31(3)(b) of the Vienna Convention as being "[...] a "concordant, common and consistent" sequence of acts or pronouncements which is sufficient to establish a discernible pattern implying the agreement of the parties [to a treaty] regarding its interpretation." ${ }^{65}$

This sequence of acts which reflects the consent of the parties or Members corresponds to what could be called a firm practice. A firm practice of Members would be relevant, in particular, for the interpretation of the provisions of the treaty in accordance with Article 31(3)(b) of the Vienna Convention to which Article 3.2 of the Understanding refers. ${ }^{66}$ In this case, the $\mathrm{AB}$ reversed the panel's finding and concluded that adopted panel reports did not constitute a practice in accordance with Article 31(3)(b) of the Vienna

63 These 6 interpretative agreements are the following: i) Understanding on the Interpretation of Article II:1(b) of the General Agreement on Tariffs and Trade 1994; ii) Understanding on the Interpretation of Article XVII of GATT 1994; iii) Understanding on Balance-of-Payments Provisions of GATT 1994; iv) Understanding on the Interpretation of Article XXIV of GATT 1994; v) Understanding in Respect of Waivers of Obligations under the GATT 1994; vi) Understanding on the Interpretation of Article XXVIII of the GATT 1994.

64 In addition to GATT 1947, 6 understandings and GATT 1994 Protocol, GATT 1994 is made up of the "provisions of the legal instruments set forth below that have entered into force under GATT 1947 before the date of entry into force of the WTO Agreement: i) protocols and certifications relating to tariff concessions; ii) protocols of accession (excluding the provisions (a) concerning provisional application and withdrawal of provisional application and (b) providing that Part II of GATT 1947 shall be applied provisionally to the fullest extent not inconsistent with legislation existing on the date of the Protocol); iii) decisions on waivers granted under Article XXV of GATT 1947 and still in force on the date of entry into force of the WTO Agreement; iv) other decisions of the CONTRACTING PARTIES to GATT 1947".

65 Report of the Appellate Body, Japan - Taxes on Alcoholic Beverages ("Japan - Alcoholic Beverages II”), Docs. WT/DS8/AB/R, WT/DS10/AB/R, WT/DS11/AB/R (adopted on 1 November 1996), DSR 1996:I, 97, 13.

66 Article 3.2 of the Understanding reads as follows: "[...] The Members recognize that it serves to preserve the rights and obligations of Members under the covered agreements, and to clarify the existing provisions of those agreements in accordance with customary rules of interpretation of public international law”. 
Convention, ${ }^{67}$ for lack of consistency. This definition of subsequent practice has, since then, been upheld in various $\mathrm{AB}$ Reports, ${ }^{68}$ and, regarding this topic, the WTO case law was even quoted in the recent Philippines $v$. China arbitral award. ${ }^{69}$ This cross-reference somewhat promotes an epistemic community around the interpretation of Article 31(3)(b), in which the WTO plays an important role. ${ }^{70}$

The existence of a subjective element also seems to be acknowledged by the Appellate Body in US - Gambling, in which it stated that:

[...] in order for 'practice' within the meaning of Article 31(3)(b) to be established: (i) there must be a common, consistent, discernible pattern of acts or pronouncements; and (ii) those acts or pronouncements must imply agreement on the interpretation of the relevant provision. ${ }^{71}$

67 If the GATT panel reports do not constitute a practice of Contracting Parties pursuant to the provisions of Article 31(3)(b) of the Vienna Convention (but create "legitimate expectations" and should therefore "be taken into consideration"), could we then consider that these previous reports - the interpretations that they may provide - constitute or contain one or several of the "rules of international law" which "should be taken into consideration" by panels, in accordance with the provisions of Article 31(3)(c) of the Vienna Convention, in the interpretation of the provisions of the WTO Treaty? Indeed, Article 38(1) of the ICJ Statute refers to "judicial decisions" as a source of international law. See Dörr, Schmalenbach, supra note 8, 561 para. 89.

68 See Report of the Appellate Body, Chile - Price Band System and Safeguard Measures Relating to Certain Agricultural Products ("Chile - Price Band System"), Doc. WT/DS207/AB/R (adopted on 23 October 2002), DSR 2002:VIII, 3045, para. 213; Report of the Appellate Body, United States - Measures Affecting the CrossBorder Supply of Gambling and Betting Services ("US - Gambling”), Doc. WT/ DS285/AB/R (adopted on 20 April 2005), DSR 2005:XII, 5663, para. 192; Report of the Appellate Body, European Communities - Customs Classification of Frozen Boneless Chicken Cuts ("EC - Chicken Cuts"), Doc. WT/DS269/AB/R (adopted on 27 September 2005), DSR 2005:XIX, 9157, para. 259.

69 Republic of the Philippines v. People's Republic of China, Permanent Court of Arbitration Case No. 2013-19, Award on Merits of 12 July 2016, para. 552.

70 The notion of epistemic community is closely linked to the debate regarding "systemic coherence" and "background theory" found in M. Koskenniemi, From Apology to Utopia - The Structure of International Legal Argument, $2^{\text {nd }}$ ed. (2005), 52-54.

71 Report of the Report of the Appellate Body, United States - Measures Affecting the Cross-Border Supply of Gambling and Betting Services ("US - Gambling"), Doc. WT/DS285/AB/R (adopted on 20 April 2005), DSR 2005:XII, 5663, para. 192. 
On the question of the subjective element, the Appellate Body went into more detail in the EC-Chicken Cuts Report:

We agree with the Panel that, in general, agreement may be deduced from the affirmative reaction of a treaty party. However, we have misgivings about deducing, without further inquiry, agreement with a practice from a party's 'lack of reaction'. We do not exclude that, in specific situations, the 'lack of reaction' or silence by a particular treaty party may, in the light of attendant circumstances, be understood as acceptance of the practice of other treaty parties. Such situations may occur when a party that has not engaged in a practice has become or has been made aware of the practice of other parties (for example, by means of notification or by virtue of participation in a forum where it is discussed), but does not react to it. However, we disagree with the Panel that 'lack of protest' against one Member's classification practice by other WTO Members may be understood, on its own, as establishing agreement with that practice by those other Members. ${ }^{72}$

The Appellate Body later upheld its findings in the EC and certain Member States - Large Civil Aircraft case:

[...] Article 31(3)(b) requires the agreement, whether express or tacit, of all WTO Members for a practice to qualify under that provision. The Appellate Body recognized that the agreement of the parties regarding a treaty's interpretation may be deduced, not only from the actions of those actually engaged in the relevant practice, but also from the acceptance of other parties to the treaty through their affirmative reactions, or depending on the attendant circumstances, their silence. ${ }^{73}$

The Appellate Body, while recognizing the possibility for silence to be conceived as an implicit acceptance of a practice, nevertheless seemed to insist on a case-by-case approach. It remains to be seen how case law pertaining to this point will evolve in the future.

72 Report of the Appellate Body, European Communities - Customs Classification of Frozen Boneless Chicken Cuts ("EC - Chicken Cuts"), Doc. WT/DS269/AB/R (adopted on 27 September 2005), DSR 2005:XIX, 9157, para. 272.

73 Report of the Appellate Body, European Communities - Measures Affecting Trade in Large Civil Aircraft ("EC and certain member States - Large Civil Aircraft”), Doc. WT/DS316/AB/R (adopted on 1 June 2011), DSR 2011:II, 7, para. 845, footnote 1916. 


\section{2. "GATT Acquis"}

In its reasoning in Japan - Alcoholic Beverages II mentioned above, the Appellate Body added, however, that adopted panel reports are an integral part of the "GATT Acquis" which is recognized by Article XVI:1 of the WTO Agreement. ${ }^{74}$ For the Appellate Body, this "GATT Acquis", and therefore the GATT 1947 jurisprudence, ${ }^{75}$ created "legitimate expectations" and had to be taken into account. ${ }^{76}$

What makes up the "GATT Acquis" is, however, ill-defined. The Appellate Body seemed to have introduced an important element in the case US $-F S C^{77}$ in which the debate concerned the legal value, in the WTO Law, of a decision adopted by the GATT Council declaring the final settlement of

74 Article XVI:1 of the WTO Agreement reads as follows: "Except as otherwise provided under this Agreement or the Multilateral Trade Agreements, the WTO shall be guided by the decisions, procedures and customary practices followed by the CONTRACTING PARTIES to GATT 1947 and the bodies established in the framework of GATT 1947".

75 The expression "jurisprudence" refers to panel reports but does not mean that the content of these reports are legally binding.

76 The Appellate Body wrote: "Article XVI:1 of the WTO Agreement and paragraph 1(b)(iv) of the text of Annex 1A incorporating the GATT 1994 into the WTO Agreement bring the legal history and experience under the GATT 1947 into the new realm of the WTO in a way that ensures continuity and consistency in a smooth transition from the GATT 1947 system. This affirms the importance to the Members of the WTO of the experience acquired by the CONTRACTING PARTIES to the GATT 1947 -- and acknowledges the continuing relevance of that experience to the new trading system served by the WTO. Adopted panel reports are an important part of the "GATT acquis". They are often considered by subsequent panels. They create legitimate expectations among WTO Members, and, therefore, should be taken into account where they are relevant to any dispute. However, they are not binding, except with respect to resolving the particular dispute between the parties to that dispute. In short, their character and their legal status have not been changed by the coming into force of the WTO Agreement", Report of the Appellate Body, Japan - Taxes on Alcoholic Beverages ("Japan - Alcoholic Beverages II"), Docs. WT/DS8/AB/R, WT/DS10/AB/R, WT/DS11/AB/R (adopted on 1 November 1996), DSR 1996:I, 97, 14 (emphasis added). In the Report of the Appellate Body, United States - Import Prohibition of Certain Shrimp and Shrimp Products, Recourse to Article 21.5 of the DSU by Malaysia ("US Shrimp (Article 21.5 - Malaysia)"), Doc. WT/DS58/AB/RW (adopted on 21 November 2001), DSR 2001:XIII, 6481, para. 109, the Appellate Body extends this line of reasoning to the Appellate Body reports.

77 Report of the Appellate Body, United States - Tax Treatment for "Foreign Sales Corporations" ("United States - FSC"), Doc. WT/DS/108/R (adopted on 20 March 2000), DSR 2000:III, 1619. 
the dispute US - Tax Legislations Cases (DISC) between the United States and the European Communities. The Appellate Body confirmed that this decision did not constitute a decision that formed part of the GATT 1994. Then it seemed to introduce a distinction between those decisions having a multilateral nature which should act as a "guide" in accordance with the provisions of Article XVI:1 of the WTO Agreement and other decisions lacking a multilateral interpretative nature. It observed that the title of the decision under examination referred to Articles XXII and XXIII of the GATT. Indeed, one may read:

113. As the Panel observed, ${ }^{78}$ it is also noteworthy that, in the report of the GATT 1947 Council to the CONTRACTING PARTIES on its actions during that year, the 1981 Council action was addressed under the heading 'Recourse to Articles XXII and XXIII. This tends to support the view that the 1981 Council action was a part of the resolution of the Tax Legislation Cases and not an authoritative interpretation of Article XVI:4 of the GATT 1947, binding on all the Contracting Parties (emphasis added).

114. In light of these surrounding circumstances, we conclude that the Panel was correct to find, in paragraph 7.85 of the Panel Report, that the 1981 Council action is not an 'other decision' under paragraph 1(b)(iv) of the language incorporating the GATT 1994 into the WTO Agreement, and does not form part of the GATT 1994. ${ }^{79}$

After calling into question, in paragraph 117, the multilateral nature of this decision related to the DISC dispute, the Appellate Body wrote:

119. We recognize that, as 'decisions' within the meaning of Article XVI:1 of the WTO Agreement, the adopted panel reports in the Tax Legislation Cases, together with the 1981 Council action, could provide 'guidance' to the WTO. [...]

124. In any event, even if the United States had been correct that the 1981 Council action could be relevant to Article 3.1(a) of the SCM Agreement, we do not believe that the 1981 Council action is of guidance in resolving this dispute because, in our view, that action does not address the issues that arise in this dispute. [...] We, therefore, believe that the 1981 Council action does not provide useful interpretative 'guidance'

78 [Original] Panel Report, para. 7.67.

79 Report of the Appellate Body, United States - Tax Treatment for "Foreign Sales Corporations" ("United States - FSC"), Doc. WT/DS/108/R (adopted on 20 March 2000), DSR 2000:III, 1619, paras. 113, 114. 
in resolving the legal issue relating to the FSC measure that is raised in this appeal. (emphasis added)

\section{The impact of the distinction between the GATT Acquis and the GATT 1994}

Should we attempt to sum up the situation, we might conclude that some "decisions" adopted by the Contracting Parties would form part of the "GATT 1994" and, in that respect, would be an integral part of the GATT 1994 and WTO primary law. Other decisions and GATT adopted panel reports ${ }^{80}$ might form part of the "GATT Acquis" in accordance with the provisions of Article XVI:1 of the WTO Agreement. Even if a decision is covered by Article XV:1 of the WTO Agreement, it is not necessarily relevant in the context of a WTO dispute. The Appellate Body seemed to have introduced a distinction between, on the one hand, (firm) "practices" in accordance with the provisions of Article 31(3)(b) of the Vienna Convention, which must be used in the interpretation of the WTO Agreement, and, on the other hand, the decisions, procedures and practices which would only provide "guidance" in accordance with the provisions of Article XVI of the WTO Agreement and which would form part of the "GATT Acquis" ${ }^{81}$ Article XVI:1 of the WTO Agreement would refer to all multilateral decisions, but maybe only some of them could serve in the interpretation of the WTO Agreement. In any event, their relevance must be assessed on a case-

80 As an example, the Appellate Body in Appellate Body Report, United States Definitive Safeguard Measures on Imports of Circular Welded Carbon Quality Line Pipe from Korea ("US - Line Pipe"), Doc. WT/DS202/AB/R (adopted 8 March 2002), DSR 2002:IV, 1403, para. 174 wrote: "Following the Vienna Convention approach, we have looked to the GATT acquis and to the relevant negotiating history of the pertinent treaty provisions. We have concluded that our view is reinforced by the jurisprudence under the GATT 1947. In the only relevant GATT 1947 case, Report on the Withdrawal by the United States of a Tariff Concession under Article XIX of the General Agreement on Tariffs and Trade ("US - Fur Felt Hats”), CP/106, 27 March 1951, the Working Party established under the GATT 1947 was required to assess the consistency of a safeguard measure with Article XIX of GATT 1947”.

81 We refer to the distinctions introduced by the Appellate Body in Report of the Appellate Body, Japan - Taxes on Alcoholic Beverages ("Japan - Alcoholic Beverages II”), Docs. WT/DS8/AB/R, WT/DS10/AB/R, WT/DS11/AB/R (adopted on 1 November 1996), DSR 1996:I, 97, and by the panel and Appellate Body in Report of the Appellate Body, United States - Tax Treatment for "Foreign Sales Corporations" ("United States - FSC"), Doc. WT/DS/108/R (adopted on 20 March 2000), DSR 2000:III, 1619. 
by-case basis. In addition, adopted panel reports would form part of the "GATT Acquis" and not of the "GATT 1994". This would create legitimate expectations which should provide guidance to the WTO. Arguably, this is where the main distinction between the two concepts lies. The practice enshrined in the "GATT 1994" constitutes a legally binding practice, integrated into the WTO Treaty, while the practice perceived as the "GATT Acquis" merely creates legitimate expectations among Members, possibly supplementing the absence of stare decisis in the WTO. ${ }^{82}$ Whether those practices are really binding is not the issue. What matters is whether they perform and they can only continue to perform because states rely on them and trust them and thus satisfactorily endorse them.

Often, the Contracting Parties adopted decisions by consensus to make the GATT provisions operational; these decisions seemed to add up to the provisions of GATT 1947. They have often been respected and followed, but it is not always easy to identify whether the Contracting Parties felt bound in a formal manner to the extent of transforming these non-binding decisions and practices into customary practices or subsequent binding practices likely to be invoked in the settlement of a dispute.

The same questions arise within the context of the WTO. The WTO bodies (Council, Committees, and Working Groups) have indeed already adopted a significant number of decisions which define, add to, supplement and implement the provisions of the treaty. Some decisions are clearly implemented pursuant to the provisions of Articles IX and X of the WTO Agreement. Sometimes the situation is more complex and this discussion raises the question whether a uniform and sustained practice of decisions is likely to change and affect the legal nature of decisions adopted by mere consensus, contrary to the provisions of the treaty or in the absence of clear provisions to that effect.

\section{$V$. The practice at the WTO: always in development}

\section{A. "Practice" at the WTO system of dispute settlement}

As an example, during the first year of the DSB, following informal consultations with Members, the DSB Chairman put in place a series of procedu-

82 Report of the Appellate Body, Japan - Taxes on Alcoholic Beverages ("Japan - Alcoholic Beverages II”), Docs. WT/DS8/AB/R, WT/DS10/AB/R, WT/DS11/AB/R (adopted on 1 November 1996), DSR 1996:I, 97,14. 
ral arrangements which would be followed as a test. For each of the practices listed below, the DSB Chairman reported to the Members the outcome of his consultations; all of this was recorded in the minutes of the meetings. ${ }^{83}$ These practices were then explained and compiled in a document which was distributed to the Members ${ }^{84}$ to appear in 2001, in the last version of the WTO official publication on "Dispute Settlement Procedures". For 9 years, these practices have always been followed by the Members and the DSB.

These working practices are the following:

1. Prescription to the effect that documents WT/DS (disputes) may only be "distributed" to the Members once they exist in the three official languages: "When there is a reference to the terms "date of circulation" or "issuance to all Members" or "issuance to the Members" in the DSU and its additional and special rules, the date to be used is the date printed on the WTO document to be circulated with the assurance of the Secretariat that the date printed on the document is the date on which this document is effectively put in the pigeon holes of delegations in all three working languages. This practice will be used on a trial basis and be subject to revision when necessary.

2. Communications to the DSB Chairman, which are related to the Understanding must be sent to the Council Division.

3. Bank holidays: computation of time-periods and notifications. When, under the DSU and its special or additional rules and procedures, a time-period within which a submission must be made or action taken by a Member to exercise or preserve its rights expires on a non-working day of the WTO Secretariat, any such submission or action will be deemed to have been made or taken on the WTO nonworking day if lodged on the first working day of the WTO Secretariat following the day on which such time-period would normally expire. ${ }^{85}$ 4. Notification of requests for consultations: All requests should be notified to the Council Divisions which would then distribute it to the

83 See for example Doc. WT/DSB/M/2 (adopted on 29 March 1995), item 7; Doc. WT/DSB/M/5 (adopted on 31 May 1995), item 8; Doc. WT/DSB/M/6 (adopted on 19 July 1995), item 10 and Doc. WT/DSB/W/10/Add.1 (adopted on 20 July 1995); Doc. WT/DSB/M/7 (adopted on 27 September 1995), item 10.

84 See Doc. WT/DSB/6 (adopted on 6 June 1996).

85 See also Doc. WT/DSB/W/10/Add.1 (adopted on 20 July 1995), containing an illustrative list of DSU provisions which refer to time-periods and Doc. WT/DSB/W/16 (adopted on 22 December 1995), indicating the WTO non-working days in 1996. 
various councils and committees; contrary to the provisions of Article 4 of the DSU, no other notification will be necessary.'

It is therefore legitimate to wonder whether those rules became binding upon the Members, as a form of subsequent practice. The discussion remains open as to whether the Members of the WTO actually consider those to be binding principles of the DSS, or simply "good practices".86

\section{B. The practice followed by the WTO Councils and Committees}

In Councils and Committees proceedings, the development of practices can purport to respond to pragmatic needs for the functioning of these bodies or help to put an end to blocked situations when powerful economic interests are opposed. Some would therefore argue that there are also institutional practices, i.e. practices of the WTO Councils, or Committees or the practices of the Dispute Settlement Body (DSB). The practice here would not be limited to Members, but would also encompass that of bodies of the WTO. The WTO Treaty contains very few institutional provisions and does not provide WTO bodies with any authority to issue secondary legislation. Various types of sui generis decisions and practices have developed to respond to the pragmatic needs of functioning of the GATT/WTO system and are said to have become (soft) practices. In particular, in this chapter, we will discuss the legal value of decisions adopted by the WTO Committees and Councils (by consensus even if contrary to the wording of the treaty) and which are subsequently followed by sustained practices. Such sustained practices could transform or reinforce informal decisions and arguably, based on the general principle of good faith and of estoppel, would bar all challenges brought against the validity of these decisions.

\section{The expansion of consensus}

Under the WTO, the practice of decision-making by consensus has been expanded. Decisions which under the GATT, were subjected to ballot, such

86 Regarding this concept in the context on environmental law, see Boisson de Chazournes, supra note 10,60 . 
as requests of accession and waivers, are now adopted by consensus ${ }^{87}$ (amendments should always be adopted by a vote of two-thirds of the Members but none has ever been adopted since the creation of the $\left.\mathrm{WTO}^{88}\right)$. The admission of Ecuador to the WTO was the first and only exception to this rule, as a vote was held. It is - incidentally - the very event which lead to the WT/L/93 decision prescribing consensus rather than vote for all future accession.

The WTO Treaty contains general provisions and sometimes specific provisions regarding decision-making within the Councils and Committees. However, all procedural rules of bodies reporting to the General Council $^{89}$ provide that their decisions will only be adopted by consensus. ${ }^{90}$ If there is no consensus, the debate may be referred to a higher committee or even the General Council. These rules may be subjected to a vote. As an example, with respect to the Council for Trade in Goods, its procedural rules provide that the General Council's procedural rules will be applied, mutatis mutandis, with the exception of some provisions, including those related to Article 33 on decision-making. Article 33 is always replaced by the following provision:

In the event a decision cannot be reached by consensus, the matter at issue will be referred to the General Council, which shall decide on the matter. ${ }^{91}$

Thus, all decisions issued by the WTO Councils, Committees and Working Groups can only be adopted by consensus. On two or three occasions, difficult questions were forwarded to the General Council, which has however, never proceeded to a vote.

87 See Doc. WT/L/93 (adopted on 24 November 1995).

88 Neither the TRIPS amendment, nor the TFA amendment has yet reached the twothirds threshold. The only exception to this absence of adoption of amendments in the WTO relates to Agreement on Government Procurement (GPA), a plurilateral agreement whose amendment came into force on 6 April 2014.

89 Adopted by consensus at the beginning of the WTO; as an example, see the following rules of procedure: Committee on Safeguards (G/SG/M/1, 24 May 1995); Committee on Anti-dumping Practices (G/ADP/M/1, 22 May 1995); Committee on Import Licensing (G/LIC/M/1, 19 June 1995).

90 The Committee on Trade and Environment applies de facto the procedural rules of the General Council and all of its decisions are adopted by consensus.

91 As an example, the Rules of procedure of the Committee on Agriculture provide that "the Committee on Agriculture shall adopt its decisions by consensus. In the event a consensus cannot be reached, the matter at issue will be referred to the Council for Trade in Goods upon the request of a delegation". 


\section{The formal recognition of the customary practice of decision-making}

Only the General Council can decide by vote. However, this possibility has never been used. The General Council has only adopted one decision by vote, on the occasion of the adoption of the Protocol of Accession of Ecuador in August 1995.92 This exercise turned out to be very complicated and, in November of the same year, the General Council adopted a decision, by consensus, providing for the effective use of consensus for accessions and waivers. This decision reads as follows:

On occasions when the General Council deals with matters related to requests for waivers or accessions to the WTO under Articles IX or XII of the WTO Agreement respectively, the General Council will seek a decision in accordance with Article IX:1. Except as otherwise provided, where a decision cannot be arrived at by consensus, the matter at issue shall be decided by voting under the relevant provisions of Articles IX or XII. ${ }^{93}$

All Protocols of Accession to the WTO since then have been adopted by consensus, notwithstanding the clear provisions of Article XII:2 of the WTO Agreement:

Decisions on accession shall be taken by the Ministerial Conference. The Ministerial Conference shall approve the agreement on the terms of accession by a two-thirds majority of the Members of the WTO. ${ }^{94}$

In practice, the General Council adopts its decisions only by consensus and even the decision under which the two last Director-Generals were appointed, following numerous difficulties, was adopted by consensus. ${ }^{95}$ Notwithstanding the proposals made by some of the Members for the adoption of new voting rules regarding the selection of the Director-General, the decision finally adopted by the General Council on 10 and 11 December 2002 confirms once again the critical importance that consensus plays in the eyes of the Members for the functioning of the WTO. Paragraph 20 of this decision provides:

92 See Doc. WT/ACC/ECU/5 (adopted on 22 August 1995).

93 See Doc. WT/L/93 (adopted on 24 November 1995).

94 See (English version) World Trade Organization, WTO Analytical Index (2002), 92, para. XIII.

95 See Doc. WT/L/308 (adopted on 22 July 1999). 
Recourse to voting as a last resort

20. If, after having carried out all the procedures set out above, it has not been possible for the General Council to take a decision by consensus by the deadline provided for the appointment, Members should consider the possibility of recourse to a vote as a last resort by a procedure to be determined at that time. Recourse to a vote for the appointment of a Director-General shall be understood to be an exceptional departure from the customary practice of decision-making by consensus, and shall not establish any precedent for such recourse in respect of any future decisions in the WTO. ${ }^{96}$ (emphasis added)

It should be noted that the WTO Agreement does not contain any provision on the selection and appointment process of the Director-General. The appointment of the Director-General would therefore be the subject of a general decision adopted by the Members by consensus in accordance with the first sentence of Article IX:1 of the WTO Agreement. The exact nature of the decisions adopted by consensus by the General Council and other WTO bodies (within the meaning of Article IX of the WTO Agreement or procedural rules of Councils and Committees) has not yet been established by the Members, or by the jurisprudence. We suggest that the practice followed subsequently by the Members, by which these decisions adopted by consensus are respected, can improve or reinforce the legal value of these decisions; in particular due to the legitimate expectations created among Members in good faith which might even bar any challenge to their validity.

It seems that two different aspects must be distinguished: First, do Members feel bound by this effectively uniform practice? Second, do they feel bound by: (1) the obligation to resort only to consensus (and therefore would voting have become banned)?, (2) the right to resort to consensus in the absence of any provision in that respect to implement the provisions of the WTO Agreement? or, (3) the right to resort to consensus in addition to the specific voting procedure provided for in the Treaty?

The obligation and the right to resort to consensus would imply that decisions adopted by consensus bind the Members; and, depending on the nature of these decisions, they might give rise to norms which are likely to be applied in the dispute settlement system. In the event of uncertainty, can the subsequent uniform practice of the Members, in conformity with

96 See Doc. WT/L/509 (adopted on 20 January 2003). 
these decisions, confirm and reinforce the binding character of norms contained in these decisions? We will briefly explore these questions.

Formally, voting can therefore be resorted to for any decisions on any matter, but in practice, WTO Members do not vote, even when they sit as the Ministerial Conference or the General Council. Often these decisions adopted by consensus are followed by a sustained and uniform practice of the Members. What is the legal value of such practices in the law of the WTO?

\section{The adoption of decisions by consensus by the General Council and other bodies, and their subsequent and sustained practices by the Members}

Regarding formal subsequent practice in the WTO, it is useful to note that the Committees and Councils are composed from every Member of the organization. Therefore, the practice of bodies could much more easily be attributed to the members composing them than in other international organizations. ${ }^{97}$ The Appellate Body itself seemed to recognize this possibility in the US - Tuna II case, while discussing the notion of subsequent agreements:

We therefore consider that the TBT Committee Decision can be considered as a 'subsequent agreement' within the meaning of Article 31(3)(a) of the Vienna Convention. The extent to which this Decision will inform the interpretation and application of a term or provision of the TBT Agreement in a specific case, however, will depend on the degree to which it 'bears specifically' on the interpretation and application of the respective term or provision..$^{98}$

One could therefore wonder if, as long as the practice fulfils the conditions of the objective and subjective elements, WTO bodies may create subsequent practice attributable to States, which would be relevant in the interpretation of the WTO Treaty.

Before discussing the legal value of commitments contained in the decisions adopted by the Councils and Committees by consensus when these decisions are followed by the practice of Members, we shall examine the

97 Boisson de Chazournes, supra note 10, 58 a contrario.

98 Report of the Appellate Body, United States - Measures Concerning the Importation, Marketing and Sale of Tuna and Tuna Products ("US - Tuna II"), Doc. WT/ DS381/AB/R (adopted on 13 June 2012), DSR 2012:IV, 1837, para. 372. 
rules governing decision-making within WTO bodies to understand the argument that these decisions are not binding.

The matter is more complicated when examining the decisions adopted by the Council and other WTO bodies in accordance with the first sentence of Article IX of the WTO Agreement, or the rules of procedure governing Councils and Committees which only provide for decision-making by consensus. What is the status in WTO law of these decisions adopted by consensus? This issue concerns the capacity of the WTO bodies to adopt decisions introducing secondary law provisions. Did the WTO bodies receive, pursuant to the WTO Agreement, the power to bind Members on the basis of decisions adopted by these bodies by consensus? If said power is not explicit, did the WTO bodies have the implicit power to adopt decisions which "implement" the primary provisions of the WTO Treaty? If this is the case, can we conclude that decisions adopted by the General Council by consensus pursuant to the first sentence of Article IX of the WTO Agreement, or by WTO other bodies in the framework of their respective rules of procedure, are in themselves binding and can be invoked in the system of dispute settlement? Can they be considered as secondary law? Otherwise, what is the legal value of these decisions? The subsequent practice of Members can create legitimate expectations and, in some circumstances, the Members may be barred from challenging their validity.

To answer these questions, we need to examine each of the decisions and provisions of the Treaty on which the decision is based. This discussion cannot provide this analysis, but sets forth some general ideas.

For instance, Protocols of Accession are adopted by consensus even though the wording of the Treaty provides for a one-third majority of the Members. No Member has seemed to challenge the binding nature of these accessions which confirm that the country in question has become a WTO Member. As an example, China has already participated in the system of dispute settlement and since recourse to the WTO Dispute Settlement System is reserved to WTO Members, it is clear that other WTO Members have recognized and accepted that China is a full WTO Member. Thus its accession process to the WTO was completed successfully. This may be an example where the subsequent uniform practice of Members, under which they have respected the terms of a decision adopted by consensus (even if contrary to the provisions of the Treaty requiring a formal voting by two-third of the Members), would confirm a tacit amendment of Article XII of the WTO Agreement. At the very least, this effective participation of the WTO governments which have acceded seems to indicate that other Members would be barred ("estopped") from challenging the validity of these Protocols of Accession. In addition, we should note that 
according to the standard Protocols of Accession (as well as cross-referred provisions of the Working Party Report). The provisions of said Protocols form an integral part of the WTO Treaty. ${ }^{99}$ This seems to confirm the intent of the Members that provisions of the Protocols of Accession are compulsory, binding and can be the basis of a claim under the DSU.

\section{The WTO practice in negotiation proceedings ${ }^{100}$}

The "Green Room" has become a generic term in the GATT/WTO and refers to the negotiation sessions held with a reduced group of Contracting Parties/Members influential with respect to a particular matter at issue. Since 1977, when the GATT moved from their premises in "La Fenêtre" and the "Bocage" to the former headquarters of the International Labour Organization, ${ }^{101}$ the "Green Room" has been and remains today primarily the working room in the GATT/WTO Director-General's office. At that time the walls were painted in green (since Director-General Ruggiero (1995-99), the room was previously salmon coloured) - hence the name "Green Room". The late nights of tiring negotiations of several rounds and multiple negotiations and informal meetings took place in the Green Room, upon the invitation of the Directors-Generals who have almost all been the Chairs of multilateral negotiations, as of right or in an "official basis". ${ }^{102}$

99 See for example Article 2 of the Protocol of Accession of Mongolia which provides that: "The WTO Agreement to which Mongolia will accede shall be the WTO Agreement as corrected, amended or otherwise modified by the legal instruments entered into force before the date of entry into force of this Protocol. This Protocol, which shall include the commitments mentioned in Paragraph 61 of the Working Group Report, shall form an integral part of the WTO Agreement" (WT/ACC/MNG/11, 25 July 1996).

100 We hereby thank Claude Mercier, Former Director at the WTO's Institute for Training, who joined the GATT in 1973, for sharing with us his knowledge on that subject.

101 154, rue de Lausanne, Geneva.

102 The General-Directors Windham White (for the first five Rounds) and Long chaired the negotiation Rounds as of right; Directors-Generals Dunkel and Sutherland chaired the negotiations of the Uruguay Round "at the level of officials"; the same applied to Directors-Generals Moore for Doha and Supachai for Cancun even though a minister of the hosting country chaired at the government level. The Ministerial Conferences since the beginning of the Uruguay Round were always chaired by the minister of trade of the hosting country: (Canada 1988), Brussels (Belgium 1990), Singapore (Singapore 1996), Switzer- 
At the WTO, the "Green Room" was seriously challenged for the first time during a preparatory meeting held in Geneva of the Ministerial Conference of Singapore of 1996, as well as in the transposition of the same type of process in Singapore. This was mainly, but not exclusively, the developing countries and the small trading states which complained to the successive Directors-Generals about the lack of transparency (because they had not been invited). The expression has since then been widely adopted by the Press, the NGOs and the anti-globalists, to express, in their eyes, the exclusion of some Members from discussions which are essential for them. The newspapers reported the holding and failures of the meetings held in the "Green Room" in Cancun. ${ }^{103}$ In fact, it was in the "Green Room" that the Mexican Minister Derbez effectively put an end to the Cancun meeting. Then the Ministerial Conference, in plenary, formally closed the meeting. ${ }^{104}$

\section{Concluding discussion}

This chapter aimed at briefly presenting the legal status of the GATT-WTO practice in international law, before introducing the various practices that were created and evolved during the life of the GATT/WTO. Rather than offering a definitive stance on the exact status of those practices, we aimed at showing the breadth of the question. A few more points, however, deserve to be mentioned and can be discussed.

Governments Members of the GATT and the WTO developed all kinds of practices. In fact, it is through these practices that the GATT managed to survive for almost 50 years in spite of its temporary legal character and its institutional weaknesses. The WTO founders recognised the vital importance of these practices since they codified them to provide "guidance" to the WTO. By institutionalising the "GATT 1994" and the "GATT Acquis", the WTO Members also codified several decisions adopted by the Con-

land (Geneva, 1998), Seattle (Seattle, 1999), Qatar (Doha, 2001), Mexico (Cancun, 2003). In fact, the only Director-General who has never chaired any meeting is Renato Ruggiero, since there has not been any negotiation under its regime with the exception of the preparatory meetings of Singapore and Geneva.

103 Bridges, "BRIDGES Daily Update on the Fifth Ministerial Conference - Issue 6, 15 September 2003" (2003), available at http://www.ictsd.org/bridges-news/bridg es/news/bridges-daily-update-6-cancun-collapse-where-theres-no-will-theres-no-w ay (last visited 6 December 2018).

104 See Doc. WT/MIN(03)/20 (adopted on 23 September 2003). 
tracting Parties by virtue of the practice of consensus. GATT practices, whatever their legal nature, now form part of the WTO "structure", either as a source of primary law (in particular in the GATT 1994) or as a guide (the GATT Acquis). Some of them are relevant in the interpretation of the GATT provisions, within the meaning of Article 31(3)(b) of the Vienna Convention.

Even today, the WTO abounds with multiple practices and the WTO defines itself from the standpoint of these various practices. This contribution has purported to present some of these practices in order to allow a better assessment of their extent and range. It is very difficult to discuss the legal value of the practices followed by the Members and the WTO bodies considering the recent development of this organization. What should be highlighted is the fact that the Members have often established numerous practices required by the needs of proceedings and other WTO actions. Confronted with a treaty which is often silent regarding the power of its bodies to implement and add to the content of the WTO Treaty. The Members seem to have preferred not to discuss the matter and to rely on pragmatic, specific and limited solutions. It is often very difficult to assess whether, in so doing, the Members intend "to commit voluntarily" or whether they only seek one or several solutions which are efficient but not compulsory and which they respect by mutual interest. We will therefore face non-compulsory norms, very important and often very efficient, but which would not be binding in the WTO system of dispute settlement.

Moreover, one could wonder whether the WTO is an exception with regards to the creation of binding norms through practice in general. In the WTO corridors, reference is often made to "the practice" for this or for that purpose. These practices do not always correspond to genuine "practices" within the meaning of international law: for instance, the practice relating to questions and responses whereby any Member that is questioned is expected to provide an answer; the practice whereby a WTO Member would not block the adoption of an entire agenda, but would limit its opposition to the item it disagrees with; the practice whereby the quorum of WTO meetings is never checked; the practice of green room meetings; or the practice of "confessional" meetings by Chairs or "facilitators" in Ministerial conferences. Many of these practices and "ways of doing things" raise very complex issues of accountability and transparency. These ways of doing however exerts an influence on the behaviour of Members and the WTO's organization of work and, in this regard, deserve discussion. They define the essentially progressive nature of this young international organization. With regard to this specific type of practice, one could also wonder whether the very use of practices resembling gentlemen's agreements could 
indicate that the Members usually do not intend to become bound, therefore possibly creating a presumption against opinio juris.

A particularly interesting aspect relates to the adoption by the General Council of a series of decisions by consensus, though the provisions of the treaty require a clear vote. We think of accessions and waivers adopted by consensus though the vote of two-thirds or three-quarters of the Members is required by the WTO Agreement. Are these decisions valid? Are the actions of Members conforming to these decisions legal? More than 18 Protocols of Accession have been adopted by consensus, sometimes in circumstances where it was not even certain that the General Council had respected its quorum. Some of these new Members are already very active and have used the system of dispute settlement. It is therefore almost unthinkable to question these actions adopted by the General Council. This does not necessarily mean that the practice of decision-making by consensus is such that all decisions adopted by consensus followed by a subsequent uniform practice of the Members are the expression of an agreement of Members on the "application of the treaty" within the meaning of Article 31(3) (a) of the Vienna Convention or a tacit amendment of the text of the WTO Agreement. Besides, to come to such a conclusion each practice and decision should be examined. However, we may conceive, in some circumstances, that the subsequent and uniform practice of Members, in addition to its interpretative value (in accordance with Article $31(3)(\mathrm{b})$ of the VCLT), might reinforce the uncertain legal value of decisions adopted by consensus contrary to the prescriptions of the treaty (in the absence of express provisions in that respect) and which, at the very least, would serve in accordance with Article 31(3)(a) of the Vienna Convention. But it is not impossible, in such circumstances, that these decisions might be implemented in the system of dispute settlement as norms of secondary law, and that pursuant to the general principle of estoppel, the Members may not challenge the validity and applicability of these decisions. The assessment of the legal value of these decisions and practices adding to, specifying and implementing the provisions of the WTO Treaty would require a more indepth discussion on the capacity of said bodies to adopt secondary or subordinate law norms binding Members.

But these questions are complex and it would probably be better not to get lost in a complex legal discussion on the nature and value of the WTO practices, as the risk of concluding that they are legally weak might undermine the institutional balance of this young organization which is faced with significant practical exigencies. But it will not always be possible to avoid this analysis, inasmuch as these same functional needs sometimes 
oblige the WTO Members and bodies to create practices, the legality of which are indeed progressive. 